MARIA NAWOJCZYK ${ }^{1}$

AGH University of Science and Technology in Kraków

Magdalena Nowicka

Humboldt-Universität zu Berlin

\title{
Transnational migration and entrepreneurial activities of migrants. Introduction
}

The individual papers collected in this part of Studia Migracyjne - Przeglad Polonijny touch upon various issues concerning entrepreneurial migration. Although each contribution looks at this topic from a different geographical perspective, their common point of reference is Poland as a country of origin of migrants and, at the same time, as a country receiving migrants. The authors refer to various classical categories applied in entrepreneurial migration studies (see, e.g., Bonacich 1973, Wilson and Portes 1980, Zhou 2004), such as: economic migration, self-employment (Sanders and Nee 1996), pulling and pushing factors for migration and entrepreneurial activity (Aaltonen and Akola 2012, Portes and Zhou 1992, Vandor and Franke 2016), ethnic entrepreneurship (Waldinger 1995, Waldinger, Aldrich and Ward 1990), and mobilization of ethnic resources and capital for economic activity (Nee and Sanders 2001, Kloosterman 2010). These categories reveal the great diversification of entrepreneurial activities of migrants (Aldrich and Martinez 2003, Kloosterman and Rath 2001). The levels of analysis in these studies often go beyond individual migrant-entrepreneur, addressing the roles played by interpersonal networks, organizational structures, populations, and broader institutional environments. Common to all the contributions is the consideration of institutional conditions of migration processes. Specifically, the context of the European Union and the process of European social and economic

${ }^{1}$ Corresponding author: Maria Nawojczyk, maria@list.pl 
integration is interesting to all the authors, as it influences the volume and the forms of flow of people within the European Union, as well as those from third countries into the EU. Thus, as some contributors argue, globalization and new technological changes are factors one needs to consider when studying how economic migration is transnationalised, and how transnational embeddedness becomes a life strategy of migrant entrepreneurs. Changes in contemporary societies toward the post-industrial paradigm and network or information societies are favorable for development of such strategies.

\section{European integration processes and economic migration in Europe}

The contributors to this volume consider European integration processes as relevant to migration and entrepreneurial activities of migrants. However, there is no clear pattern regarding how the legal framework of the European Union matters for migration and entrepreneurship. The workings of the European Union are manifold. First, the single market regulations, in particular the free movement of labour, enables citizens of any European Union member state to undertake employment in another state (Directive 2004/38/EC). Poland joined the European Union in May 2004, yet when we look at the long-term migration statistics, we see that flows from Poland to Germany have been continuously growing since the waiving of the visa requirements, and that the accession to the EU did not result in a significant peak of the volume of migration. This might be caused by the fact that Germany, as well as Austria, applied transitional regulations which significantly limited the access of citizens of the so-called new accession countries to their labour markets, but when these regulations were abandoned in 2011, no significant increase in migration from Poland to these countries was recorded.

On the other hand, the opening of the labour markets of Great Britain, Ireland, and later also other 'old' EU member states to the citizens of new accession countries did cause a new wave of migration from Poland, and from other Central Eastern European countries, to these states. Małgorzata Patok's study in this volume shows the European Union's effects on self-employment practices through the experience of Polish immigrants employed in low-skilled occupations in France. When we look specifically at the number of Polish migrant entrepreneurs abroad, on the other hand, we can see an increase in Germany which cannot be explained by either the increase of the number of Poles in this country, or by changes to their legal status related to the Polish accession to the EU. Polish people have a large stake in the UK economy as well; they established nearly 22,000 companies across the country (CFE 2015). In the same time Poland become a country receiving migrants. In 2017, according to Eurostat, Poland issued 683,000 job permits for foreigners ( $22 \%$ of all permits in the EU), Germany - 535,000 (17\%), Great Britain - 517,000 
(16\%), and France - 250,000 (8\%). Thus the economic migration is highly dynamic, and all EU countries experience growing internal mobility (within the EU) and are at the same time attractive for immigration from non-EU countries. The flow of economic migrants to Poland is organized in case of Special Economic Zones being researched by Marta Songin-Mokrzan and is spontaneous, as in the case presented in this volume by Katarzyna Andrejuk and Olena Oleksiyenko. However, these authors do not focus on the largest group of economic migrants in Poland, those from Ukraine.

Thus, the impact of the European integration process on economic migration and migrant entrepreneurship requires a more sophisticated lens, one that looks beyond the legal frameworks. As the contributions to this volume show, such a lens needs to consider how nation-states wield their power over the life-courses of migrants, for example by (not) acknowledging their qualifications, or by structuring the economic conditions of their functioning. These state or EU policies must take globalization processes into account as well (see, e.g., Castles and Miller 2003, Kloosterman and Rath 2003, Tarrow 2005).

\section{The meaning of migrant entrepreneurship}

The European Union, as well as other European institutions, promotes selfemployment of migrants and migrant entrepreneurship as a path to integration of migrants into host societies. Migrants create their own jobs when they become entrepreneurs, and in the best cases they create jobs for other migrants as well. In doing so, they may also improve the overall social and economic position of the immigrant community to which they belong (Rath and Swagerman 2011, Official Journal of the EU 2012). Yet sociologists are sceptical whether self-employment is indeed a path to successful integration of migrants. It could lead to social exclusion, but it could also be profitable depending on the history of a given ethnic enclave and the waves of migration within that enclave (Portes and Shafer 2007). The sociological studies are showing that a universal pattern of relations between migrants' self-employment and their ability to integrate into a host society is strongly influenced by culture, politics, and institutional frameworks.

As Katarzyna Andrejuk (2016) shows, migrant entrepreneurs are more successful if they are already well-integrated in the society, having, for example, the necessary language skills and some knowledge of the legal system. Only then can they fully utilize their ethnic capital. However, this may be true for some but not all ethnic groups and contexts (Kogan 2004, Nowicka 2013). Some groups are more likely than others to have their ethnicity considered as an advantage, although this may also be a serious limitation to what kind of businesses they may successfully engage in. For example, Italians in Sweden may have a competitive 
advantage as ice-cream or pizza makers, but not as engineers, and Thai women in Germany are more likely to succeed in the beauty and health sector but not as electricians, and so on. Similarly, Polish migrants in Austria are more likely to run a handicraft company, but not an architecture firm. Such findings show that integration through self-employment is not a one-sided process, but the outcome of negotiations of meaning of ethnicity as capital between migrants and the socalled majority-society. The more open and tolerant the society, the more likely will self-employment be a path to successful integration in the long term. Otherwise, as Ludger Pries (2010) put it, migrant entrepreneurship might become an 'ethnic trap. Even if ethnic companies do offer a opportunity for new migrants to enter the labour market, the longer these migrants stay in an ethnic sector of an economy, the fewer chances they have to better their economic positions and improve their social capital. The challenge thus, as Katarzyna Andrejuk and Olena Oleksiyenko argue in their contribution to the current volume, is how to assure that migrants can use their ethnic capital in an 'non-alienating' manner. The concept of 'multiple embeddedness' and a focus on balanced attention on ethnic networks and culture as well as regulatory environment could open new research perspectives for understanding ethnic entrepreneurship and entrepreneurial agency on the community level (Pang and Rath 2007). That triggers an interesting discussion on how ethnic enclaves can persist, even symbolically, when they are challenged by non-ethnic enterprises.

The second reason for the European institutions to promote entrepreneurial activities of migrants is that regional and local economies may significantly profit from migrant entrepreneurs. Accordingly, migrants may revitalise neighbourhoods badly affected by economic stagnation and unemployment, providing new flair to them, or they may be vital to the restructuring of selected sectors of an economy (Davidaviciene and Lolat 2016). The contribution from Anna Skraba and Magdalena Nowicka demonstrates that the relatively deprived region in Germany bordering Poland can indeed profit from the entrepreneurial activities of Polish migrants. On the other hand, whole sectors, such as construction, may rely on migrant labour. Yet there is again a down-side to this process for migrants who gain access to local labour markets only as owners or employees of sub-contracting migrant firms, instead of directly finding employment in Germany. Whether this hinders their integration in the long term or not is still subject to further research (see Ram, Jones and Villares-Varela 2017). Skraba and Nowicka propose viewing migrant entrepreneurship from a relational perspective which considers equally the social and economic developments in the place of origin and destination of migrants. The contributions presented in this volume take other perspectives as well: contextual - emphasising the role of material and cultural environments; behavioural - examining the structure and processes of entrepreneurial activity on a micro-level; constructivist - implicating the influence of entrepreneurship 
over industrial sectors, communities, and economies as a whole; and ecological analysing the direct impact of material and cultural environments on economic and institutional development.

\section{Transnationalism as a resource in entrepreneurship}

Whether migrants indeed struggle for long-term integration abroad cannot yet be our normative presumption but an empirical question, for we need to consider that the process of European integration enables migrants to lead their lives across nation-state borders (see, e.g., Lin and Tao 2012, Brzozowski, Cucuulelli and Surdej 2014, Portes 2003, Portes, Guarnizo and Haller 2002, Nowicka 2005). The contributions to this volume demonstrate that being socially embedded in more than one country might become a valuable resource for migrants. Migrants-entrepreneurs can use social capital and resources from countries of origin and destination, exercising 'multiple embeddedness' to be more competitive.

However, transnationalism of migrants' lives needs to be considered with reference to the institutional context, as Songin-Mokrzan reminds us in her contribution. It is the transnational networks established by companies which enforce transnationalism among migrant workers, not vice versa. Transnationalism, thus, requires some sort of infrastructure, as Maria Nawojczyk and Lidia Synowiec-Jaje show, and this could consist of a dense network of organisations supporting entrepreneurs from their country of origin, in their native languages. In this sense, non-migrant companies can also become transnational operators, and support transnationalism or migrant entrepreneurs. The growing saturation of globalization of economic activity and mobility of people over spaces determine new approaches to relations between transnationalism and entrepreneurship (Faist 2000, Hannerz 1996, Light 2007). Development of the new technologies is contributing to this change as well. The rise of network societies rewards cultural diversity particularly in the creative sector, but in another economic activities as well. Economies and states open for migration of entrepreneurial people will profit from these flows under the condition that all sides of these relations are willing to cooperate with each other.

\section{References}

Aaltonen S. and Akola E. (2012). Lack of trust - the main obstacle for immigrant entrepreneurship? http://pyk2.aalto.fi/ncsb2012/Aaltonen.pdf [July 2018]

Aldrich H.E. and Martinez M. (2003) Entrepreneurship as Social Construction: A Multi-Level Evolutionary Approach. In: Acs Z.J. and Audretsch D.B. (eds) Handbook of Entrepreneurship. Boston-Dordrecht-London: Kulwert Academic Publisher, pp. 359-399.

Andrejuk K. (2016). Self-employed migrants from EU Member States in Poland: differentiated professional trajectories and explanations of entrepreneurial success. https://www.tandfonline.com/doi/abs/10.1080/1369183X.2016.1249050 [October 2018]. 
Bonacich E., (1973). Theory of Middleman Minorities. "American Sociological Review", 38, pp. 583-594.

Brzozowski J., Cucculelli M. and Surdej A., (2014). The determinants of transnational entrepreneurship and transnational ties' dynamics among immigrant entrepreneurs in ICT sector in Italy, https://www.uniba.it/ricerca/dipartimenti/dse/e.g.i/30Brzozowski.pdf [September 2018]

Castles S., Miller M.J. (2003), The Age of Migrations, New York: Guilford Press.

CFE (2015). Migrant Entrepreneurs: Building Our Businesses Creating Our JOBs https://centreforentrepreneurs.org/wp-content/uploads/2015/11/MigrantEntrepreneursWEB.pdf [October 2018]

Davidaviciene V. and Lolat I. (2016). Migrant entrepreneurship in Europe: challenges and opportunities. https://www.researchgate.net/publication/303562782_MIGRANT_ENTREPRENEURSHIP_IN_EUROPE_CHALLENGES_AND_OPPORTUNITIES [October 2018]

Directive 2004/38/EC of the European Parliament and of the Council of 29 April 2004 on the right of citizens of the Union and their family members to move and reside freely within the territory of the Member States amending Regulation (EEC) No 1612/68.

Faist T. (2000). The Volume and Dynamics of International Migration and Transnational Social Spaces, Oxford: Oxford University Press.

Hannerz U. (1996). Transnational Connections. Culture, People, Places, London: Routledge.

Kloosterman, R. C. (2010). Matching opportunities with resources: A framework for analysing (migrant) entrepreneurship from a mixed embeddedness perspective. "Entrepreneurship and Regional Development", 22(1), pp. 25-45.

Kloosterman, R. and Rath, J. (2001). Immigrant entrepreneurs in advanced economies: mixed embeddedness further explored. "Journal of Ethnic and Migration Studies", 27(2), pp. 189-201.

Kloosterman R. and Rath J. (eds). (2003). Immigrant Entrepreneurs: Venturing Abroad in the Age of Globalization. Oxford: Berg.

Kogan I. (2004). Last Hired, First Fired? The Unemployment Dynamics of Male Immigrants in Germany, "European Sociological Review”, vol. 20 number 5, pp. 445-461.

Light I. (2007). Global Entrepreneurship and Transnationalism. In: Dana L-P (ed.) Handbook of Research on Ethnic Minority Entrepreneurship: Edward Elgar Publishing, pp. 3-15.

Lin X. and Tao S. (2012). Transnational entrepreneurs: Characteristics, drivers, and success factors, http://ccibd.ca/wp-content/uploads/2015/07/JIE-TE.pdf [September 2018]

Nee V. and Sanders J. (2001). Understanding the diversity of immigrant incorporation: a forms-of-capital model. "Ethnic and Racial Studies" 24(3), pp. 386-411.

Nowicka M. (2005). Transnational Professionals and their Cosmopolitan Universes. Frankfurt and New York: Campus Verlag.

Nowicka M. (2013). Positioning Strategies of Polish Entrepreneurs in Germany: Transnationalizing Bourdieu's Notion of Capital, https://edoc.hu-berlin.de/bitstream/handle /18452/14257/27GinRDuatcT6.pdf?sequence=1 [September 2018]

Official Journal of the EU (2012). Opinion of the European Economic and Social Committee on 'The contribution of migrant entrepreneurs to the EU economy'. https://publications.europa.eu/en/publication-detail/-/publication/379c0bfb-2f0d-11e2-9b72-01aa75ed71a1/language-en [October 2018]

Pang C. L. and Rath J. (2007). The force of regulation in the land of the free: the persistence of Chinatown, Washington DC as a symbolic ethnic enclave. In: Ruef M. and Lounsbury M. (eds.) The Sociology of Entrepreneurship. Amsterdam: Elsevier, pp. 191-219. 
Portes A. (2003). Conclusion: Theoretical Convergencies and Empirical Evidence in the Study of Immigrant Transnationalism. "International Migration Review", 37(3), pp. 874-892.

Portes A., Guarnizo L.E. and Haller W.J. (2002). Transnational Entrepreneurs: An Alternative Form of Immigrant Economic Adaptation. "American Sociological Review" 67(2), pp. 278-298.

Portes A. and Shafer S. (2007). Revisiting the enclave hypothesis: Miami twenty-five years later. In: Ruef M. and Lounsbury M. (eds.) The Sociology of Entrepreneurship. Amsterdam: Elsevier, pp. 157-190.

Portes A. and Zhou M. (1992). Gaining the Upper Hand: Economic Mobility among Immigrants and Domestic Minorities. "Ethnic and Racial Studies", 15, pp. 491-522.

Pries L. (2010). Transnationalisierung: Theorie und Empirie grenzüberschreitender Vergesellschaftung. Springer-Verlag

Ram, M., Jones, T. and Villares-Varela, M. (2017). Migrant entrepreneurship: Reflections on research and practice. "International Small Business Journal", 35(1), pp. 3-18.

Rath J. and Swagerman A. (2011). Promoting ethnic entrepreneurship in European cities. https://www.coe.int/t/democracy/migration/Source/migration/congress_public_3.pdf [October 2018].

Sanders J. and Nee V. (1996). Immigrant Self-Employment: The Family as Social Capital and the Value of Human Capital. "American Sociological Review", 61(2), pp. 231-249.

Tarrow S. (2005). The New Transnational Activism, New York: Cambridge University Press.

Vandor, P., Franke, N., (2016). Why Are Immigrants More Entrepreneurial? https://hbr.org/ 2016/10/why-are-immigrants-more-entrepreneurial [July 2018]

Waldinger R. (1995). The 'other side' of embeddedness. A case-study of the interplay of economy and ethnicity. "Ethnic and Racial Studies", 18(3), pp. 555-580.

Waldinger R., Aldrich H.E. and Ward R. (1990). Ethnic Entrepreneurs. London: Sage.

Wilson K. and Portes A. (1980). Immigrant Enclaves: An Analysis of the Labor Market Experience of Cubans in Miami, "American Journal of Sociology", vol. 86, pp. 295-319.

Zhou M. (2004). Revisiting Ethnic Entrepreneurship: Convergencies, Controversies, and Conceptual Advancements, "International Migration Review" Volume 38, Issue 3, September 2004, pp. 1040-1074. 